\title{
The use of meloxicam oral suspension to treat musculoskeletal lameness in cattle
}

This article was published in the following Dove Press journal:

Veterinary Medicine: Research and Reports

II November 2016

Number of times this article has been viewed

\author{
D Nagel' \\ R Wieringa ${ }^{2}$ \\ J Ireland ${ }^{3}$ \\ Merle E Olson' \\ 'Solvet/Alberta Veterinary \\ Laboratories, Calgary, AB, ${ }^{2}$ Heartland \\ Veterinary Services, Listowel, \\ ${ }^{3}$ Albadon Farm Ltd, Teeswater, \\ ON, Canada
}

Correspondence: Merle E Olson Solvet/Alberta Veterinary Laboratories, 4I I 19th Street SE, Calgary, AB T2E 6J7, Canada

Tel +l 4034562245

Fax + I 4032076074

Email merle@avetlabs.com

\begin{abstract}
Lameness in beef and dairy cattle is responsible for economic losses and has significant animal welfare implications. It has been proposed that early treatment with analgesics not only reduces acute pain but also leads to reduced long-term sensitization. Fifty-three cattle (309-954 kg body weight [BW], mean: $656 \mathrm{~kg}$ ) with musculoskeletal lameness were scored for lameness and inflammation, then randomly assigned to a single oral treatment with meloxicam oral suspension (MOS) (28 animals) at $1 \mathrm{mg} / \mathrm{kg}$ or saline at $1 \mathrm{~mL} / 15 \mathrm{~kg}$ BW. Lameness and inflammation were reevaluated 3 days after treatment, and 26 of 28 (92.8\%) MOS-treated animals had a reduced lameness score, while only three of 25 control animals had a reduced lameness score. MOS was effective in treating musculoskeletal disease in cattle. In an accompanying residue depletion study, 22 lactating Holstein cows (BW: 553-927 kg, mean: $713 \mathrm{~kg}$ ) were used in the study. All 22 animals received MOS at the dose of $1 \mathrm{mg} / \mathrm{kg} \mathrm{BW}$ once. Milk (500 mL sample from the full milking volume) was collected at approximately 48, 72, 96, and 120 hours after the treatment. Samples were subjected to in vitro analysis for quantification of meloxicam by liquid chromatography and mass spectroscopy. The mean meloxicam concentration at 48 and 72 hours were 30.75 and $2.82 \mathrm{ng} / \mathrm{mL}$, respectively. The meloxicam milk concentration was below the limit of quantification $(1 \mathrm{ng} / \mathrm{mL})$ in 15 of 22 animals at 96 hours and in 22 of 22 animals at 120 hours. The milk meloxicam levels in all animals were below the maximum residue limit (Canada: $35 \mathrm{ng} / \mathrm{mL}$; Europe: $15 \mathrm{ng} / \mathrm{mL}$ ) at the 72-hour sampling.
\end{abstract}

Keywords: meloxicam, lameness, musculoskeletal, residue, milk, cattle

\section{Introduction}

Lameness in beef and dairy cattle is responsible for economic losses and has significant animal welfare implications. ${ }^{1-3}$ The causes of musculoskeletal disorders include traumatic injury (eg, handling injuries, pen riding, and slipping), arthritis, hoof abnormalities, infections (infectious pododermatitis and infectious arthritis), and causes of unknown etiology. Lameness constitutes a major cause of involuntary culling of cattle in both the beef and dairy industries, and a prevalence of over $30 \%$ has been reported in some herds. ${ }^{1}$ It has been proposed that early treatment with an effective analgesic not only reduces acute pain but also leads to reduced long-term sensitization. ${ }^{1}$ A multimodal approach to treatment is generally recommended. ${ }^{1}$ These include interventions such as corrective foot trimming, local anesthetic antibiotics (if there is an infections component), and nonsteroidal anti-inflammatory drugs. ${ }^{1,4}$ Meloxicam is a newer nonsteroidal anti-inflammatory drug in the oxicam group that has preferential (but not specific) binding to cyclo-oxygenase-2 receptors and has been shown to reduce 
pain and inflammation in food and companion animals. ${ }^{4}$ Meloxicam oral suspension (MOS) was recently registered for control of pain and inflammation in surgically and bandcastrated cattle. ${ }^{5}$ MOS has also been shown to effectively treat musculoskeletal disease in horses. ${ }^{6}$ The objective of this study was to determine the efficacy of MOS for the treatment of noninfectious musculoskeletal disorders in cattle. As dairy cattle frequently require treatment for musculoskeletal lameness, a milk residue depletion study was conducted to establish a milk withdrawal time.

\section{Methods}

Both studies were conducted in compliance with the guidelines of the Canadian Council on Animal Care after the appropriate review and approval by the Institutional Animal Care and Use Committee of Alberta Agriculture, Airdrie, Alberta. A prestudy proportion power calculation was performed to determine the number of animals required to generate meaningful results. With improvement proportions of 0.6 for MOS and 0.2 for saline, it was determined that a minimum of 18 animals in each group were required. Procedures were designed to avoid or minimize discomfort, distress, and pain to the animals.

\section{Lameness efficacy study}

Animals having noninfectious musculoskeletal lameness were identified by collecting the history of the animal and by performing a physical examination. Cattle with musculoskeletal disease were selected from 15 different herds and varied in sex, age, location of disease, and severity of lameness (Table 1). Animals were on a winter pasture in the area of Calgary, Alberta, Canada, and were provided hay and mineral supplement and had free access to water. They were randomly allocated to treatment and control groups. Treatment animals received MOS (Solvet/Alberta Veterinary Laboratories [AVL], Calgary, AB, Canada) at an oral dose of $1 \mathrm{mg} / \mathrm{kg}$ body weight (BW) $(\mathrm{n}=28)$, and control animals $(\mathrm{n}=25)$ received saline $1 \mathrm{~mL} / 15 \mathrm{~kg} B W$. Individuals in charge of the preparation of dosing syringes, treating the animals, and randomization were not blinded. The person evaluating lameness in each animal was blinded.

The degree of lameness was scored using a 0-4 scale (Table 2) adapted from Sprecher et al. ${ }^{1,7}$ Lameness scores were determined on day 0 (Treatment day) and day 3 (3 days after first treatment). To eliminate interobserver variation, all lameness scores were assigned by a single-blinded veterinarian (Dr. Denis Nagel) with training and expertise in bovine lameness assessment. All lameness examinations were performed on even, nonsloped floors free of obstructions and debris. Each lameness score was determined by watching the animal walk a minimum of $20 \mathrm{~m}$ in a straight line, turn, and walk $20 \mathrm{~m}$ back to the starting point.

On day 0 and day 3 (at the times of the lameness evaluation), swelling (inflammation) in the most affected limb was evaluated according to the details listed in Table 2 . The same veterinarian performed all the inflammation scores.

\section{Data analysis}

The proportion of animals in each group responding to treatment was compared using Fisher's exact test. Nonparametric analysis (Mann-Whitney $U$ test) was used to compare lameness scores between treatment groups. Significance was established at a 95\% confidence interval, and data are expressed as median, mean, and standard error with $P$ values.

\section{Residue depletion study}

The study was conducted according to the Veterinary International Cooperation on Harmonization Guidelines for residue depletion (VICH GL48 ${ }^{\circledR}$ ). ${ }^{8}$ Twenty-two lactating Holstein cows (BW: 553-927 kg, mean: $713 \mathrm{~kg}$ ) from a single farm were enrolled into the study. Animals varied in age from 1.9 to 8.5 years (mean: 3.9 years.) with the number of lactations varying from 1 to 6 (mean: 2.4). The days lactating varied from 55 to 539 days (mean: 215.9 days). All 22 animals were healthy and remained healthy during the adaptation period (prior to day 0), the treatment period (day 0), and the elimination period (0-144 hours). Cattle were treated with MOS at a dosage of $1 \mathrm{mg} / \mathrm{kg} \mathrm{BW}$ on day 0 , and the time of treatment was recorded. Milk samples were collected at approximately 48, 72, 96, 120, and 144 hours after treatment. The milk sampling times were recorded for each animal. The entire milking was collected, and a $500 \mathrm{~mL}$ subsample was taken and frozen at $-20^{\circ} \mathrm{C}$ until analysis.

Analysis of milk meloxicam was performed under VICH GL49 ${ }^{\circledR}$ guidelines in the Canadian Food Inspection Agency Certified Laboratory (Silliker, JR Laboratories, Burnaby, BC, Canada). ${ }^{8}$ Meloxicam was analyzed in the milk samples using a validated procedure (Canadian Food Inspection Agency, CVDR-M-3025.03) using liquid chromatography and mass spectroscopy. The limit of quantification was $1 \mathrm{ng} / \mathrm{mL}$ (1 ppb).

\section{Results}

\section{Lameness efficacy study}

All animals ( 2 males, 2 male castrates, and 49 females, all mature) were enrolled, allocated, and treated without incident. A total of 28 animals received MOS, while 25 animals received 
Table I Descriptions of animals selected for musculoskeletal study

\begin{tabular}{|c|c|c|c|c|c|}
\hline Number & Owner & Description & Age (years) & Sex & Body weight (kg) \\
\hline I & 1 & Hereford & 11 & $\mathrm{~F}$ & 805 \\
\hline 2 & 2 & Hereford & 7 & $\mathrm{~F}$ & 750 \\
\hline 3 & 2 & Hereford & 11 & $\mathrm{~F}$ & 727 \\
\hline 4 & 3 & Angus & 6 & $\mathrm{~F}$ & 616 \\
\hline 5 & 3 & Angus & 13 & $\mathrm{~F}$ & 680 \\
\hline 6 & 4 & Hereford X & 5 & $\mathrm{~F}$ & 682 \\
\hline 7 & 4 & Charolais $\mathrm{X}$ & 8 & $\mathrm{~F}$ & 786 \\
\hline 8 & 4 & Angus & 7 & $\mathrm{~F}$ & 704 \\
\hline 9 & 4 & Angus & I & MC & 309 \\
\hline 10 & 5 & Angus & 6 & $\mathrm{~F}$ & 590 \\
\hline II & 5 & Angus & 6 & $\mathrm{~F}$ & 613 \\
\hline 12 & 5 & Angus & 7 & $\mathrm{~F}$ & 795 \\
\hline 13 & 5 & Angus & 5 & $\mathrm{~F}$ & 682 \\
\hline 14 & 5 & Angus & 4 & $M$ & 954 \\
\hline 15 & 5 & Angus & 12 & $\mathrm{~F}$ & 568 \\
\hline 16 & 5 & Angus & 6 & $\mathrm{~F}$ & 680 \\
\hline 17 & 6 & Angus $X$ & 8 & $\mathrm{~F}$ & 727 \\
\hline 18 & 6 & Simmental $\mathrm{X}$ & 5 & $\mathrm{~F}$ & 750 \\
\hline 19 & 6 & Angus $X$ & 6 & $\mathrm{~F}$ & 804 \\
\hline 20 & 6 & Angus $X$ & 5 & $\mathrm{~F}$ & 681 \\
\hline 21 & 7 & Angus & 5 & $\mathrm{~F}$ & 680 \\
\hline 22 & 7 & Angus & 6 & $\mathrm{~F}$ & 750 \\
\hline 23 & 8 & Hereford & 2 & $M$ & 863 \\
\hline 24 & 8 & Hereford & 6 & $\mathrm{~F}$ & 738 \\
\hline 25 & 8 & Hereford & 7 & $\mathrm{~F}$ & 660 \\
\hline 26 & 8 & Hereford & 7 & $\mathrm{~F}$ & 590 \\
\hline 27 & 9 & Charolais $\mathrm{X}$ & 10 & $\mathrm{~F}$ & 659 \\
\hline 28 & 9 & Charolais $X$ & 10 & $\mathrm{~F}$ & 640 \\
\hline 29 & 9 & Charolais X & 12 & $\mathrm{~F}$ & 705 \\
\hline 30 & 9 & Charolais $X$ & 10 & $\mathrm{~F}$ & 682 \\
\hline 31 & 9 & Charolais $X$ & 13 & $\mathrm{~F}$ & 614 \\
\hline 32 & 9 & Charolais $\mathrm{X}$ & 11 & $\mathrm{~F}$ & 705 \\
\hline 33 & 9 & Charolais $\mathrm{X}$ & 12 & $\mathrm{~F}$ & 546 \\
\hline 34 & 9 & Charolais $X$ & 11 & $\mathrm{~F}$ & 614 \\
\hline 35 & 10 & Hereford & 3 & $\mathrm{~F}$ & 522 \\
\hline 36 & 10 & Hereford & 11 & $\mathrm{~F}$ & 636 \\
\hline 37 & 11 & Angus & 3 & $\mathrm{~F}$ & 545 \\
\hline 38 & 11 & Angus & 11 & $\mathrm{~F}$ & 682 \\
\hline 39 & 12 & Hereford & 10 & $\mathrm{~F}$ & 704 \\
\hline 40 & 13 & Simmental $\mathrm{X}$ & 14 & $\mathrm{~F}$ & 613 \\
\hline 41 & 13 & Simmental $\mathrm{X}$ & 6 & $\mathrm{~F}$ & 568 \\
\hline 42 & 13 & Angus & 1 & $M C$ & 360 \\
\hline 43 & 14 & Hereford $X$ & 12 & $\mathrm{~F}$ & 590 \\
\hline 44 & 14 & Hereford X & 10 & $\mathrm{~F}$ & 636 \\
\hline 45 & 15 & Simmental $\mathrm{X}$ & 12 & $\mathrm{~F}$ & 590 \\
\hline 46 & 15 & Angus & 9 & $\mathrm{~F}$ & 681 \\
\hline 47 & 15 & Charolais $X$ & 12 & $\mathrm{~F}$ & 600 \\
\hline 48 & 15 & Simmental $\mathrm{X}$ & 7 & $\mathrm{~F}$ & 636 \\
\hline 49 & 15 & Angus & 5 & $\mathrm{~F}$ & 590 \\
\hline 50 & 15 & Charolais X & 10 & $\mathrm{~F}$ & 636 \\
\hline 51 & 15 & Angus & 10 & $\mathrm{~F}$ & 682 \\
\hline 52 & 15 & Simmental $\mathrm{X}$ & 10 & $\mathrm{~F}$ & 590 \\
\hline 53 & 15 & Angus & 6 & $\mathrm{~F}$ & 602 \\
\hline
\end{tabular}

Abbreviations: $F$, female; $M$, male; $M C$, male castrate. 
Table 2 Lameness and inflammation scoring

\begin{tabular}{lll}
\hline Score & Severity & Description \\
\hline Lameness scoring & \\
0 & Normal & Stands and walks normally, with all feet placed with purpose \\
I & Mildly lame & Stands with flat back but arches when walks and gait is slightly abnormal \\
2 & Moderately lame & Stands and walks with an arched back and short strides with one or more legs \\
3 & Lame & Arched back standing and walking, with one or more limbs favored but at least partially weight-bearing \\
4 & Severely lame & Arched back, refuses to bear weight on one limb, or may refuse or have great difficulty moving from lying position \\
Inflammation scoring & \\
0 & No inflammation & No swelling observed \\
I & Mild & Slight swelling observed on limb or foot \\
2 & Moderate & Moderate swelling on the limb and/or foot \\
3 & Severe & Severe swelling of limb and/or foot \\
\hline
\end{tabular}

saline. There were no adverse events following either treatment. The treatment results are summarized in Table 3. The lameness involves the foot (22), fetlock (4), stifle (16), and hip (11). There was no difference in lameness scores between the MOS and saline groups in the pretreatment period $(P=0.635)$. The scores on day 3 (approximately 3 days after treatment) were significantly less in the MOS treatment group than in the saline-treated animals $(P<0.0001)$. The scores on day 0 and day 3 were also significantly different between the MOS- and saline-treated animals $(P<0.0001)$. Animals receiving MOS responded positively to treatment in 26 of 28 cases $(92.8 \%)$, while saline controls responded in three of 25 cases (12\%).

There were 42 animals with hind-limb lameness and eleven with front-limb lameness. There were only eight animals (four in each treatment group) with limb swelling associated with lameness. In the MOS-treated group, four of four had reduced inflammation scores, while there was no improvement in any saline-treated animals. When inflammation occurred, there was a significant reduction in swelling in the MOS-treated compared to saline-treated animals $(P=0.0286)$.

\section{Residue depletion study}

The duration from treatment to sample collection and milk meloxicam concentrations is provided in Table 4 . The duration of time between treatment and milk sampling was less than or equal to the target times in 15, 16, and 17 of the 22 animals at 48,72, and 96 hours, respectively. The maximum collection times were no more than 30 minutes over the target times. The mean meloxicam concentration at 48 and 72 hours were 30.75 and $2.82 \mathrm{ng} / \mathrm{mL}$, respectively. The meloxicam milk concentration was below the limit of quantification $(1 \mathrm{ng} / \mathrm{mL})$ in 15 of 22 animals at 96 hours and 22 of 22 animals at 120 hours. In all animals, the milk meloxicam levels were well below the maximum residue limit (Canada: $35 \mathrm{ng} / \mathrm{mL}$; Europe: $15 \mathrm{ng} / \mathrm{mL}$ ) at the 72-hour sampling. ${ }^{9,10}$

\section{Discussion}

The economic and animal welfare impact of lameness has been documented in numerous studies and reviews. ${ }^{1-3}$ Lameness causes involuntary culling of beef and dairy cattle and is usually underreported by producers. ${ }^{1,2}$ Early analgesic treatment intervention may affect the outcome of lameness as this can prevent hyperalgesia (increased sensitivity to pain). Hyperalgesia can contribute to chronic lameness and culling. ${ }^{1}$ A multimodal approach to lameness treatment with the use of analgesics, corrective trimming, and antibiotics can reduce cases of chronic lameness and culling. ${ }^{1}$ Nonsteroidal antiinflammatory drugs have been demonstrated to be effective in reducing lameness associated using a visual locomotion score. ${ }^{1,4}$ Sodium salicylate, flunixin, and ketoprofen have had mixed results in the treatment of musculoskeletal lameness in both field and experimental models. ${ }^{1,11,12}$ This may be due to the short half-life and the ability to penetrate the affected tissues. ${ }^{4}$ There are recent studies that have shown meloxicam to be effective in the treatment of musculoskeletal disease in horses. ${ }^{6}$ Meloxicam has also been shown to be effective in the treatment of experimental lameness model in cattle. ${ }^{13}$ Postoperative treatment with meloxicam after cesarean section and resection of the distal interphalangeal joint has been shown to be effective in increasing comfort and effective analgesia. ${ }^{14,15}$ This study has shown that meloxicam reduces inflammation and decreases lameness scores for 3 days after a single treatment. The long half-life (27 hours) and high response rate $(92.8 \%)$ make MOS ideally suited for the treatment of musculoskeletal disease in cattle. ${ }^{4}$ Pharmacokinetics and milk secretion of oral meloxicam and gabapentin in a limited number of cattle have been previously reported with similar residue depletion in milk. ${ }^{16}$ Although the milk withdrawal time has not been established for MOS at the time this article was published, the milk concentration in all 22 animals in this study are well below the Canadian and European maximum residue limits at 72 hours posttreatment. 


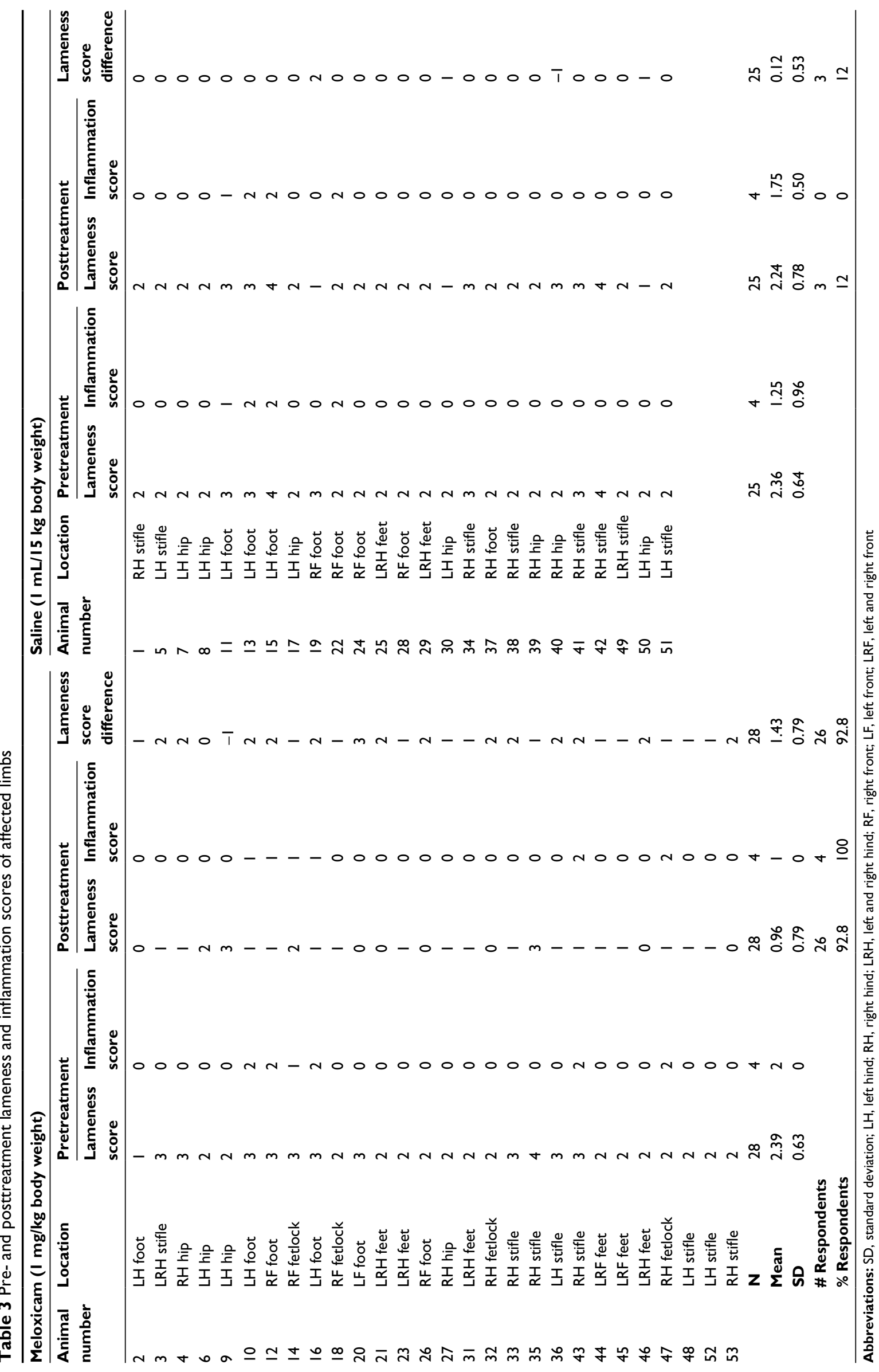


Table 4 Meloxicam in milk after administration of MOS $(\mathrm{ng} / \mathrm{mL})$

\begin{tabular}{|c|c|c|c|c|c|c|c|c|}
\hline \multirow[t]{3}{*}{ Animal } & \multicolumn{8}{|c|}{ Milk meloxicam concentration $(\eta g / m L) n g$} \\
\hline & \multicolumn{2}{|l|}{ 48-hour sample } & \multicolumn{2}{|l|}{ 72-hour sample } & \multicolumn{2}{|l|}{ 96-hour sample } & \multicolumn{2}{|c|}{ | 20-hour sample } \\
\hline & $\begin{array}{l}\text { Real duration } \\
\text { (hour:minute) }\end{array}$ & $\begin{array}{l}\text { Milk } \\
\text { meloxicam } \\
(\eta g / m L)\end{array}$ & $\begin{array}{l}\text { Real duration } \\
\text { (hour:minute) }\end{array}$ & $\begin{array}{l}\text { Milk } \\
\text { meloxicam } \\
(\eta g / m L)\end{array}$ & $\begin{array}{l}\text { Real duration } \\
\text { (hour:minute) }\end{array}$ & $\begin{array}{l}\text { Milk } \\
\text { meloxicam } \\
(\eta g / m L)\end{array}$ & $\begin{array}{l}\text { Real duration } \\
\text { (hour:minute) }\end{array}$ & $\begin{array}{l}\text { Milk } \\
\text { meloxicam } \\
(\eta g / m L)\end{array}$ \\
\hline I & $47: 35$ & 14.46 & $71: 45$ & 2.64 & $95: 30$ & $<1.0$ & $119: 20$ & $<1.0$ \\
\hline 2 & 48:05 & 19.30 & $71: 45$ & 1.94 & $95: 30$ & 1.11 & $118: 35$ & $<1.0$ \\
\hline 3 & $46: 55$ & 22.24 & $71: 10$ & 1.99 & $95: 10$ & $<1.0$ & $119: 15$ & $<1.0$ \\
\hline 4 & 48:05 & 15.83 & $71: 55$ & $<1$ & $96: 05$ & $<1.0$ & $120: 10$ & $<1.0$ \\
\hline 5 & $46: 45$ & 24.31 & $71: 10$ & 3.67 & $95: 05$ & $<1.0$ & II8:45 & $<1.0$ \\
\hline 6 & $48: 00$ & 12.50 & 72:05 & I.II & $96: 05$ & $<1.0$ & $120: 05$ & $<1.0$ \\
\hline 7 & $47: 35$ & 26.99 & $71: 30$ & 3.66 & $95: 35$ & $<1.0$ & $119: 30$ & $<1.0$ \\
\hline 8 & $47: 40$ & 26.16 & $71: 45$ & 2.79 & $95: 25$ & $<1.0$ & $119: 35$ & $<1.0$ \\
\hline 9 & $47: 15$ & 43.46 & $71: 10$ & 3.12 & $95: 15$ & $<1.0$ & $119: 05$ & $<1.0$ \\
\hline 10 & $47: 20$ & 50.54 & $71: 25$ & 5.14 & $95: 15$ & 1.29 & $119: 30$ & $<1.0$ \\
\hline 11 & $47: 40$ & $|5.5|$ & $71: 45$ & 2.53 & $95: 35$ & $<1.0$ & $119: 35$ & $<1.0$ \\
\hline 12 & $47: 35$ & 46.12 & 71:33 & 4.22 & $95: 25$ & $<1.0$ & $119: 30$ & $<1.0$ \\
\hline 13 & 48:05 & 19.60 & $71: 40$ & 3.60 & $96: 05$ & $<1.0$ & $120: 05$ & $<1.0$ \\
\hline 14 & $47: 40$ & 27.15 & $71: 45$ & 1.47 & $95: 45$ & $<1.0$ & $119: 45$ & $<1.0$ \\
\hline 15 & $47: 10$ & 39.20 & $70: 48$ & 3.45 & $94: 35$ & $<1.0$ & $118: 55$ & $<1.0$ \\
\hline 16 & 48:00 & 44.54 & 72:06 & 2.69 & $95: 41$ & 1.15 & $|2|: 00$ & $<1.0$ \\
\hline 17 & $48: 15$ & 44.16 & 72:06 & 3.70 & $95: 50$ & $<1.0$ & $120: 17$ & $<1.0$ \\
\hline 18 & $47: 55$ & 46.42 & $72: 10$ & 3.78 & $95: 40$ & 1.59 & $120: 05$ & $<1.0$ \\
\hline 19 & $48: 20$ & 20.86 & $72: 30$ & 1.32 & $96: 08$ & $<1.0$ & $120: 30$ & $<1.0$ \\
\hline 20 & $48: 25$ & 21.44 & $72: 20$ & 3.72 & $95: 54$ & $<1.0$ & $120: 20$ & $<1.0$ \\
\hline 21 & $48: 27$ & 28.79 & $72: 27$ & 1.30 & $96: 07$ & 1.37 & $120: 15$ & $<1.0$ \\
\hline 22 & 48:05 & 67.00 & $71: 57$ & 3.30 & $95: 36$ & 1.25 & $120: 05$ & $<1.0$ \\
\hline Mean & $47: 46$ & 30.75 & $71: 45$ & 2.82 & $95: 36$ & 1.08 & $119: 44$ & N/A \\
\hline Median & $47: 47$ & 26.58 & $71: 45$ & 2.96 & $95: 35$ & 1.00 & $119: 40$ & $\mathrm{~N} / \mathrm{A}$ \\
\hline Minimum & $46: 45$ & 12.5 & $70: 48$ & $<1.00$ & $94: 35$ & $<1.00$ & $118: 35$ & $\mathrm{~N} / \mathrm{A}$ \\
\hline Maximum & $48: 27$ & 67.00 & $72: 30$ & 5.14 & $96: 08$ & 1.59 & $121: 00$ & $\mathrm{~N} / \mathrm{A}$ \\
\hline SD & $0: 28$ & 14.56 & $0: 26$ & 1.13 & $0: 23$ & 0.16 & $0: 36$ & $N / A$ \\
\hline \# < MRL & & 14 & & 22 & & 22 & & 22 \\
\hline$\%<$ MRL & & 63.6 & & 100 & & 100 & & 100 \\
\hline
\end{tabular}

Abbreviations: N/A, not applicable; SD, standard deviation; MRL, maximum residue limit; MOS, meloxicam oral suspension.

\section{Disclosure}

$\mathrm{DN}, \mathrm{RW}, \mathrm{JI}$, and MEO received funding from AVL to conduct the study. There was no influence in the preparation of manuscript, interpretation of data, and conclusions from AVL. The authors report no other conflicts of interests in this work.

\section{References}

1. Shearer JK, Stock ML, van Amstel SR, Coetzee JF. Assessment and management of pain associated with lameness in cattle. Vet Clin North Am Food Anim Pract. 2013;29(1):135-156.

2. Willshire JA, Bell NJ. An economic review of cattle lameness. Cattle Pract. 2009;17(2):136-141.

3. Scott PR. The challenges to improve farm animal welfare in the United Kingdom by reducing disease incidence with greater veterinary involvement. Animals. 2013;3:629-646.

4. Stock LM, Coetzee JF. Clinical pharmacology of analgesic drugs in cattle. Vet Clin North Am Food Anim Pract. 2015;31(1):113-138.

5. Olson ME, Ralston B, Burwash L, Matheson-Bird H, Allan N. Efficacy of oral meloxicam suspension for prevention of pain and inflammation following band and surgical castration in calves. BMC Vet Res. 2016;12(1):102.
6. Olson ME, Nagel D, Custead S, et al. The palatability and comparative efficacy of meloxicam oral suspension for the treatment of chronic musculoskeletal disease in horses. J Equine Vet Sci. 2016;44:26-31.

7. Sprecher DJ, Hostetler DE, Kaneene JB. A lameness scoring system that uses posture and gait to predict dairy cattle reproductive performance. Theriogenology. 1997;47(6):1179-1187.

8. VICH. Metabolism and Residue Kinetics. Available from: http://www. vichsec.org/guidelines/pharmaceuticals/pharma-safety/metabolismand-residue-kinetics.html. Accessed April 25, 2016.

9. The European Agency for the Evaluation of Medicinal Products. Committee for Veterinary Medicinal Products. The European Agency for the Evaluation of Medicinal Products; 1999. Available from: http://www. ema.europa.eu/docs/en_GB/document_library/Maximum_Residue_Limits_-_Report/2009/11/WC500014953.pdf. Accessed April 25, 2016.

10. http://www.hc-sc.gc.ca/dhp-mps/vet/mrl-lmr/mrl-lmr_versus_newnouveau-eng.php. List of Maximum Residue Limits (MRLs) for Veterinary Drugs in Foods. Accessed April 25, 2016.

11. Flower FC, Sedlbauer M, Carter E, von Keyserlingk MA, Sanderson DJ, Weary DM. Analgesics improve the gait of lame dairy cattle. J Dairy Sci. 2008;91(8):3010-3014.

12. Laven RA, Lawrence KE, Weston JF, Dowson KR, Stafford KJ. Assessment of the duration of the pain response associated with lameness in dairy cows, and the influence of treatment. $N$ Z Vet J. 2008;56(5): $210-217$. 
13. Coetzee JF, Mosher RA, Anderson DE, et al. Impact of oral meloxicam administered alone or in combination with gabapentin on experimentally induced lameness in beef calves. J Anim Sci. 2014;92:816-829.

14. Offinger J, Herdtweck S, Rizk A et al. Postoperative analgesic efficacy of meloxicam in lame dairy cows undergoing resection of the distal interphalangeal joint. J Dairy Sci. 2013;96(2):866-876.
15. Barrier AC, Coombs TM, Dwyer CM, Haskell MJ, Goby L. Administration of a NSAID (meloxicam) affects lying behaviour after caesarean section in beef cows. Appl Anim Behav Sci. 2014;155:28-33.

16. Malreddy PR, Coetzee JF, KuKanich B, Gehring R. Pharmacokinetics and milk secretion of gabapentin and meloxicam co-administered orally in Holstein-Friesian cows. J Vet Pharmacol Ther. 2013;36(1):14-20.
Veterinary Medicine: Research and Reports is an international, peer-reviewed, open access journal publishing original research case reports, editorials, reviews and commentaries on all areas of veterinary medicine. The manuscript management system is completely online and includes a very quick and fair peer-review system.
Visit http://www.dovepress.com/testimonials.php to read real quotes from published authors. 